protects the form of expression of the result, but not its essence. Therefore, copyright is not enough to ensure proper protection of artificial intelligence.

Due to the fact that the future lies in artificial intelligence, we consider it necessary to provide for the possibility of indicating in applications for registration of intellectual property objects the information that the result was created by an artificial intelligence system, but with a mandatory indication of the author-developer of such artificial intelligence. This will allow for providing reliable information, because a developer of artificial intelligence cannot always predict the results of "activities" of such creation, respectively, it is not always objective to consider him as the author of such results of artificial intelligence. At the same time, artificial intelligence is the result of the activities of its author, respectively, because it is a programmed object, it cannot be unambiguously considered the author of all results that it will achieve because of such programming.

\title{
References:
}

1. Концепція оновлення Цивільного кодексу України. Київ: Видавничий дім «АртЕк», 2020.128 с.

2. Івченко А. О. Тлумачний словник української мови. Харків: Фоліо, 2006. 540 c.

3. Суд в США визначив, що штучний інтелект не може бути зазначений як винахідник у патентах. URL: https://ukrpatent.org/ uk/news/main/DABUS-10092021 (дата звернення: 28.09.2021р.).

DOI https://doi.org/10.30525/978-9934-26-148-0-23

\section{РОЗПОДІЛ СУДОВИХ ВИТРАТ ПРИ РОЗГЛЯДІ СПРАВИ СУДОМ НЕНАЛЕЖНОЇ ЮРИСДИКЦІї}

\author{
Короєд С. О. \\ доктор юридичних наук, професор, професор кафедри права \\ ЗВО «Університет Короля Данила» \\ м. Івано-Франківськ, Україна
}

В юридичній літературі під судовими витратами зазвичай розуміють витрати осіб, які беруть участь у розгляді справи, а у випадках їх звільнення від сплати судових витрат - держав, які вони несуть у зв'язку 3 розглядом та вирішенням конкретної справи. Основним призначенням інституту судових витрат $€$ відшкодування учасникам процесу витрат, пов'язаних із розглядом справи: оплата правової допомоги, 86 
відшкодування сторонам, їх представникам, свідкам, спеціалістам, перекладачам, експертам витрат, пов'язаних із переїздом до іншого населеного пункту, найманням житла, виплатою добових (у разі переїзду до іншого населеного пункту), компенсація за втрачений заробіток чи відрив від звичайних занять. Крім того, вони служать певним важелем для здійснення впливу на поведінку учасників процесу та запобігання неправомірній та недобросовісній процесуальній поведінці [1, с. 439, 440-441]. Компенсаційна функція судових витрат реалізується через механізм розподілу судових витрат. В основу розподілу витрат між сторонами покладений загальний принцип, відповідно до якого відповідальність за шкоду покладається на особу, дією або бездіяльністю якої заподіяна шкода [2, с. 125].

Проте, як свідчить аналіз положень процесуального законодавства та судової практики, мета компенсаційної функції судових витрат не досягається при закритті провадження у справі, зокрема через подання позову до суду неналежної юрисдикції. Наприклад, при розгляді справи № 810/5133/18, в якій провадження було закрито, оскільки цю справу не належить розглядати за правилами адміністративного судочинства, суд відмовив третій особі у стягнення судових витрат (витрат на правову допомогу), оскільки судами не було підтверджено необгрунтованих дій позивача при пред'явленні позову до суду неналежної юрисдикції.

Так, дійсно, виходячи 3 положень процесуальних законів, у разі закриття провадження у справі відповідач має право заявити вимоги про компенсацію здійснених ним витрат, пов'язаних 3 розглядом справи, лише внаслідок необгрунтованих дій позивача (ч. 5 ст. 142 ЦПК України, ч. 10 ст. 139 КАС України). Проте, виходячи із принципів повного відшкодування заподіяних збитків, справедливості та розумності, залишається незрозумілим, яким чином повинно вирішуватись питання компенсації (відшкодування) відповідачу і третім особам витрат, пов'язаних з розглядом справи, провадження в якій в майбутньому буде закрито. Закон, процесуальна наука та судова практика відповіді на це питання не дають.

Відсутність можливості такої компенсації судових витрат, на нашу думку, порушує передусім засади справедливості, адже змушує відповідачів і третіх осіб, за відсутності їхньої вини та об'єктивної потреби в цьому (адже судове провадження ініціювали не вони), нести зокрема витрати на професійну правничу допомогу та витрати, пов'язані із прибуттям до суду у справі, розпочатій за зверненням позивача, але провадження в якій в майбутньому закривається через подання позову до суду неналежної юрисдикції. 3 іншого боку, якщо відповідач все ж таки якось ще може розраховувати на компенсацію здійснених ним 
витрат, пов'язаних з розглядом справи (внаслідок необгрунтованих дій позивача - на підставі ч. 5 ст. 142 ЦПК України), то позивач такого права не має, оскільки взагалі відсутнє законодавче регулювання компенсації здійснених позивачем витрат, пов'язаних з розглядом справи, якщо провадження в справі закривається апеляційним судом або Верховним Судом з мотивів подання позову до суду неналежної юрисдикції, адже ч. 9 ст. 141 ЦПК України, яка передбачає можливість покладення судових витрат незалежно від результатів вирішення спору на сторону у випадку зловживання нею процесуальними правами, стосується випадку, якщо спір виник внаслідок неправильних дій сторони, може бути застосована лише за результатами вирішення справи по суті, що дозволить встановити причину виникнення спору і неправильність дій сторін (відповідача або позивача чи обох сторін) в його виникненні, що при закритті провадження у справі встановлюватись судом не може, оскільки права та взаємовідносини сторін і обставини (юридичні факти), які зумовили виникнення цих правовідносин, судом не встановлюються.

Отже можна зробити висновок, що на відміну від положень ч. 5 ст. 142 ЦПК України, яка стосується необгрунтованих дій позивача саме в процесуальному аспекті (тобто дії по пред'явленню безпідставного позову та дії в процесі, які характеризуються зловживанням процесуальними правами), положення ч. 9 ст. 141 ЦПК України більше стосується неправильних дій сторони в матеріально-правовому сенсі, які призвели до виникнення спору і можуть бути встановлені лише за результатами вирішення такого спору (тобто при ухваленні рішення по суті спору).

Свого часу ми вже обгрунтовували об'єктивну потребу у зміні процесуального регулювання інституту підвідомчості в цивільному судочинстві, передбачивши обов'язок суду передавати справу (в цілому або в частині позовних вимог) за підвідомчістю на розгляд суду іншої юрисдикції, скасувавши таку підставу для закриття провадження у справі, як непідвідомчість [3, с. 109], щоб таким чином справа не припинялася, а питання розподілу судових витрат в подальшому в межах цієї справи було вирішено судом належної юрисдикції. I лише минулого року згідно із Законом № 460-IX від 15.01.2020 статті 377 і 414 ЦПК України було доповнено відповідними положеннями. Але для того, щоб зазначений "механізм передачі справи до суду належної юрисдикції” все ж таки забезпечував вирішення питання розподілу судових витрат в межах конкретної справи, на наш погляд, необхідним $\epsilon$ застосування зазначеного механізму не в добровільному порядку (за заявою позивача), а виключно в обов'язковому порядку та встановлення правила про вирішення питання щодо розподілу судових витрат саме за 88 
результатами вирішення такої справи по суті. А відтак, коли справа, після закриття в ній провадження в порядку одного виду судочинства, буде в безумовному порядку передаватись на розгляд до суду належної юрисдикції в порядку іншого виду судочинства, то позивач в силу засад диспозитивності в подальшому сам вирішуватиме, чи відмовлятися йому від позову (залишити його без розгляду) або ж продовжити захист своїх прав в суді належної юрисдикції. В цьому випадку тоді вже можна буде застосувати загальний механізм розподілу судових витрат, тобто відповідні встановлені процесуальним законом правила розподілу судових витрат при вирішенні справи по суті (ст. 141 ЦПК України) або ж правила розподілу судових витрат при закритті провадження у справі (у зв'язку із відмовою від позову чи укладенням мирової угоди) чи залишення позову без розгляду (ст. 142 ЦПК України).

Іншим варіантом забезпечення вирішення питання розподілу судових витрат у випадку закриття провадження із вищезазначених підстав може бути встановлення для позивача процесуального строку (наприклад в один місяць) з моменту закриття провадження у справі на підставі п. 1 ч. 1 ст. 255 ЦПК України на подачу заяви в порядку статей 377 і 414 ЦПК України про передачу справи до суду належної юрисдикції. В такому випадку неподання позивачем в зазначений строк такої заяви варто розцінювати як зловживання процесуальними правами (адже позивач ініціював провадження в суді неналежної юрисдикції і не бажає його продовжити в суді належної юрисдикції з метою доведення обгрунтованості своїх вимог і неправомірності дій відповідача), що й буде підставою для вирішення питання розподілу судових витрат тим судом, який закрив провадження у справі, з урахуванням положень або ч. 9 ст. 141 або ч. 5 ст. 142 ЦПК України.

\section{Література:}

1. Курс цивільного процесу: підручник / В. В. Комаров, В. А. Бігун, В. В. Баранкова та ін.; за ред. В. В. Комарова. Х.: Право, 2011. 1352 с.

2. Васильєв С. В. Цивільний процес: Навчальний посібник. Х.: ТОВ »Одіссей», 2008. 480 с.

3. Короєд С. О. Процесуальне забезпечення ефективності цивільного судочинства: дис. ... докт. юрид. наук: 12.00.03. К., 2014. 489 с. 